\title{
Improvement on high-cholesterol diet induced atherosclerosis, lipid profile, oxidative stress and genotoxicity in the liver of mice by Echinops spinosissimus Turra subsp. spinosus
}

Donyez Frikha Dammak ( $\sim$ fdonyez@yahoo.com )

Universite de Sfax

Hajer Ben Saad

Universite de Sfax

Emna Bouattour

Universite de Sfax Faculte des Sciences de Sfax

Ons Boudawara

Universite de Sfax Faculte de Medecine de Sfax

Raoudha Mezghani Jarraya

Universite de Sfax Faculte des Sciences de Sfax

Research article

Keywords: hypercholesterolemia, lipid profile, antioxidant, Echinops spinosus flower, mice

Posted Date: March 24th, 2020

DOI: https://doi.org/10.21203/rs.3.rs-18432/v1

License: (c) (i) This work is licensed under a Creative Commons Attribution 4.0 International License.

Read Full License 


\section{Abstract}

Background Hypercholesterolemia is a major risk factor for the development of atherosclerosis and endothelial dysfunction.

Methods The present study investigates the possible mechanism of Echinops spinosissimus Turra subsp. spinosus ( E. s. spinosus ) flower on the high cholesterol diet.

Results Our in vitro results demonstrated the richness of E.s. spinosus flower in antioxidant compounds, and its antioxidant activities. The co-administration of E.s. spinosus ( 100 or $200 \mathrm{mg} / \mathrm{kg} / \mathrm{day}$ ) with highfat diet attenuated hepatotoxicity as monitored by the improvement of oxidative stress biomarkers and plasma lipid and liver parameters, when compared to the hypercholesterolemic mice. Atherogenic index and body weight were also reduced markedly, compared to control mice. These results were confirmed by the improvement of histological changes and DNA damage.

Conclusion These data indicate that E.s. spinosus flower reduces the hypercholesterolemia risk and atherogenic properties of dietary cholesterol. Its hypocholesterolemic effect may be due to its antioxidant activities and its richness in bioactive molecule.

\section{Introduction}

Hypercholesterolemia is a dominant risk factor for the development and progression of atherosclerosis, related cardiovascular diseases, and many lipid associated ailments like obesity, liver and kidney failure $[1,3]$. Epidemiological, clinical, genetic, and experimental studies indicate that a diet high in cholesterol content is a major environmental contributor to an unbalanced lipoprotein [4]. The effect of

hypercholesterolemia in vivo has been studied with different animal species. Sparks et al. [5] reported for the first time that hypercholesterolemia affects $\beta$-amyloid in rabbits [6, 7]. Recently, Granholm and colleagues [8] demonstrated that hypercholesterolemia in rats increase the number of working memory errors. It has been reported that high levels of fat increase fat-mediated oxidative stress and decrease antioxidant enzyme activities [9].

Based on this evidence, many therapeutic agents are available for the management of hypercholesterolemic patients and are employed to promote successful treatment. A number of studies have demonstrated that the use of lipid-lowering drugs can reduce the number of cardiovascular events and mortality from coronary disease [10]. However, due to certain resistances to dietary restriction and financial limitations to use lipid-lowering drugs, many individuals have turned to alternative treatments to control cholesterol levels. Many of these alternative treatments have been used empirically, lacking scientific studies that would allow for more reliable conclusions [11]. In recent years, there has been an increasing interest in antioxidants which play a crucial role in food industry and in providing protection for humans against infections and degenerative diseases [12]. Many studies describe the crucial role of the most important group of secondary metabolites, flavonoids and phenolics compounds, as natural 
antioxidants in health promotion by reducing the risk of hyperlipidemic diseases and protecting biological systems against the harmful effects of oxidative processes [13].

Echinops spinosissimus (Asteraceae) is a traditional medicinal plant that is abundant in the desert of Egypt and Tunisia [14]. Many researches have subdivided Echinops spinosissimus Turra into two subspecies: Echinops spinosissimus Turra subsp bovei and Echinops spinosissimus Turra subsp. spinosus (E. s. spinosus) [15]. The latter is drought resistant specie of high medicinal value. E. spinosissimus has been highly reputed as a diuretic, nerve tonic and cough suppressant, and contains a range of sesquiterpene lactones migraine, diarrhea, intestinal worm infestation and hemorrhoids [16]. This specie has high medicinal value due to the presence of functional flavonoids and phenols. Concerning the genus E. s. spinosus, the ethanolic extract has efficient action on muscular fibers and exhibited a very good anti-inflammatory activity [16]. It was known for its therapeutic effect on health and its extensive anecdotal history in traditional medicines [17]. The Gas chromatography and Mass spectrometry analysis demonstrated that the plant is a potential source of terpenoid compounds and acetylated sterols [17].

The diet-induced hypercholesterolemia animal model has long been used for the assessment of agents with beneficial effects on cholesterol. Therefore, the present investigation was performed to document the effects of E. s. spinosus flower on a high cholesterol diet in mice.

\section{Material And Methods}

\section{Plant material}

Echinops spinosissimus TURRA subsp. spinosus (E. s. spinosus) was harvested from Sfax Governorate, Tunisia. The collected plant was identified by Professor Mohamed Chaieb Botanist of the biology and Plant Ecology, Department of Biology in the Faculty of Science of Sfax. A voucher specimen of E. S. spinosus was deposited at the Laboratory of Chemistry of Natural Substances, Faculty of Sciences of Sfax, Tunisia.

\section{Preparation Of Extracts}

The dried flower heads of E. s. spinosus ( $500 \mathrm{~g}$ ) were extracted sequentially by maceration in hexane, dichloromethane, ethyl acetate (EtOAc), and $\mathrm{MeOH}$ at room temperature, for 48 hours. After filtration, the solvents were evaporated under vacuum at $50^{\circ} \mathrm{C}$ to afford $6.9,4.9,7.3$ and $19.1 \mathrm{~g}$, respectively.

\section{Determination Of Total Phenolic Content}

The amount of total phenolic content was evaluated using a slightly modified colorimetric method described by Singleton and Rossi [18] using the Folin-Ciocalteu reagent. The absorption was measured at 
$760 \mathrm{~nm}$ by spectrophotometer. The estimation of the phenolic compounds was carried out in triplicate and the results was expressed as gallic acid equivalents (GAE, mg gallic acid/per g of extract).

\section{Determination Of Total Flavonoid Content}

Total flavonoid contents of flower heads E. S. spinosus were determined using the aluminium trichloride colorimetric method [19]. The total flavonoid content was expressed as mg of quercetin (QE)/g of extract.

\section{Phytochemical Studies}

All the plant extracts were subjected to preliminary phytochemical screening following the standard methods [20], to detect the presence of active principles such as sterols, triterpenoïds, tropolone, quinones, alkaloïds, and flavonoïds.

A sample of each extract is dissolved in $2 \mathrm{~mL}$ of solvent adequate then will be added to various reagents according to the methods cited below:

Test for sterols and triterpenoïds: (Reaction of Liebermann). $1 \mathrm{~mL}$ of acetic anhydride and few drops of concentrated sulphuric acid were mixed to the extracts solution and a violet changing to blue-green indicate a positive test for sterols and (or) triterpenoïds.

Test for flavonoïds: (Shinoda test). The stock extract solution $(1 \mathrm{~mL})$ was taken in a test tube and added to $1 \mathrm{~mL}$ of EtOH, $1 \mathrm{~mL}$ of distillated water and a few drops of dilute Hydrochloric acid. A positive reaction was recorded when an intense red violet coloration was appeared which become after blue.

Test for alkaloïds: (Mayer Reaction). Test solution $(1 \mathrm{~mL})$ when treated with $0.5 \mathrm{~mL}$ of $\mathrm{HCl}(0.1 \mathrm{~N})$ and 5 drops of Mayer reagent shows immediately a white precipitate showed the presence of alkaloïds.

Test for tropolone: (Reaction of Wiustater). It was manipulated by adding $\mathrm{MeOH}(0.2 \mathrm{~mL}), 1$ drop of $\mathrm{FeCl}_{3}$ $(0.005 \mathrm{M})$, water $(0.6 \mathrm{~mL})$ and $\mathrm{CHCl}_{3}(0.4 \mathrm{~mL})$ to $1 \mathrm{~mL}$ of our test solution. A red colour of the chloroform layer was formed which showed the presence of tropolone.

Test for quinones: (Reaction of Borntraeger). To detect the presence of quinones in our extracts, $2 \mathrm{~mL}$ of each solution sample was mixed with $2 \mathrm{~mL}$ of $\mathrm{NaOH}(0.1 \mathrm{M})$. The changement of coloration in the aqueous phase from red to purple would show a positive result for the presence of quinones.

\section{Antioxidant Capacity Estimation}

Three methods of antioxidant assessment, $\beta$-carotene bleaching by linoleic acid assay, Diphenylpicrylhydrazyl (DPPH) radical scavenging and ferric-reducing anti-oxidant power were used for investigation of antioxidant activities of E. s. spinosus flower heads extracts. These results were compared to those of a-tocopherol, BHT and gallic acid used as positive control.

\section{Ferric-reducing antioxidant power (FRAP) assay}


The FRAP method measure the ability of an antioxidant to donate electron to Fe (III), which could be monitored at $700 \mathrm{~nm}$. This assay was carried out according to the procedure employed by Oyaizu with slight modifications [21]. Absorbance of the reaction mixture was read spectrophotometrically at $700 \mathrm{~nm}$.

FRAP result was expressed as gallic acid equivalents (GAE) in $\mathrm{mg} / \mathrm{g}$ of tested sample.

$y=0.775 x+0.117 ; r^{2}=0.906$

\section{DPPH free radical scavenging assay}

The antioxidant activity of DPPH is based on scavenging of DPPH. from antioxidants in the vegetal sample, which produce a spectrophotometric loss in absorbance at $515 \mathrm{~nm}$. The DPPH assay was evaluated as described by [22]. The mixture was prepared in test tubes by dilution of $50 \mu \mathrm{L}$ of ALE in $735 \mathrm{~mL}$ of $100 \%$ methanol. $750 \mathrm{~mL}$ of $0.1 \mathrm{mM}$ methanolic DPPH reagent was added to the mixture of ALE-methanol. Then, the mixture was incubated at room temperature in a chamber without any light during $30 \mathrm{~min}$. After incubation, the estimation of the scavenging ability was performed by measuring at $517 \mathrm{~nm}$ in spectrophotometer (T70 UV-Vis).

The capacity of inhibition percentage (PI) of DPPH radicals was calculated as

DPPH radicals $(\mathrm{PI})=\left[\left(A_{b}-A_{s}\right) / \mathrm{A}_{\mathrm{b}}\right] \times 100$

Where $A_{b}$ refers to the absorbance of control (without plant extract) and $A_{s}$ to the absorbance of sample (with plant extract).

BHT was used as standard at the same concentrations of plant extracts.

\section{Antioxidant assay using the $\beta$-carotene bleaching method}

The antioxidant activity of the E. s. spinosus flower was evaluated using $\beta$-carotene bleaching method as described by Chevolleau et al. [23] with some modification. All determinations were carried out in triplicate.

The antioxidant activity coefficient (AAC) was calculated according to the following equation:

$A A C=[(A A(120)-A C(120)) /(A C(0)-A C(120))] \times 100$

$A A C=$ Absorbance of extract $(120 \mathrm{~min})-$ Absorbance of control ${ }_{(120 \mathrm{~min})}$

Absorbance of control (0min) - Absorbance of control (120min)

\section{Animal Diet And Tissue Preparation}

This study was performed in accordance with the Institute Ethical Committee for the Care and Use of Laboratory Animals guidelines [24] and Sciences Faculty of Sfax ( $\left.{ }^{\circ} 1204\right)$ [25]. Adult mice (30 $\left.\pm 5 \mathrm{~g}\right)$ were 
randomly divided into four groups of 12 animals each; group received either no treatment (control group), hypercholesterolemic group receiving $1 \%$ cholesterol and $0.5 \%$ choline, group receiving $1 \%$ cholesterol + $0.5 \%$ choline associated with E. s. spinosus flower methanolic extract a dose of $100 \mathrm{mg} / \mathrm{kg}$ of diet; mice receiving $1 \%$ cholesterol $+0.5 \%$ choline associated with E.s. spinosus flower methanolic extract at a dose of $200 \mathrm{mg} / \mathrm{kg}$ of diet. During the experimental period (30 days), food and water intake of the animals was monitored daily. At the end of the experimental period, the animals of different groups were killed by cervical decapitation to avoid stress. The liver was quickly excised, rinsed in Tris- $\mathrm{HCl}$ buffer, weighed, and then divided into three parts. One part was homogenized in Tris- $\mathrm{HCl}$ buffer, as indicated in the procedures of oxidative stress markers. The other two parts were used in molecular assays and some samples were immediately removed, cleaned, fixed in $10 \%$ buffered formalin solution for $48 \mathrm{~h}$, and then embedded in paraffin for histological analysis.

\section{Protein Quantification}

Protein content in the liver was assayed following the methods previously described by Lowry et al [26].

\section{Determination of Oxidative Stress Markers}

We determined the amount of malondialdehyde (MDA) in the liver using 1,1,3,3-tetraethoxypropane and following the methods described by Draper and Hadley [27]. The values are expressed as nmol MDA/mg protein.

Advanced oxidation protein products (AOPPs) were assayed using the method described by Witko [28]. The level of AOPP in liver tissue was calculated using an extinction coefficient of 261 and expressed as $\mu \mathrm{mol} / \mathrm{mg}$ protein.

Protein carbonyls (PCO) were measured using the method of Reznick and Packer [29]. The absorbance of the sample was measured at $370 \mathrm{~nm}$. The carbonyl content was calculated based on the molar extinction coefficient of DNPH (5 $2.23104 \mathrm{~cm} / \mathrm{M}$ ) and expressed as nmoles/mg protein.

Superoxide dismutase (SOD) enzyme activity was measured using the method described by Beauchamp and Fridovich [30]. One unit of SOD activity was defined as the amount of enzyme required to cause a $50 \%$ inhibition of nitro blue tetrazolium photoreduction. SOD activity in cerebellar tissue is expressed as units/mg protein.

Glutathione peroxidase (GPx) enzyme activity was measured using the method described by Flohe and Gunzler [31]. We calculated the modification in absorbance at $340 \mathrm{~nm}$. GPx enzyme activity is expressed as $\mathrm{nmol} \mathrm{GSH} / \mathrm{min} / \mathrm{mg}$ protein.

Liver reduced glutathione (GSH) contents were determined by Ellman's method [32], and modified by Jollow et al. [33], based on the development of a yellow color when 5,5-dithiobis-2 nitro benzoic acid was 
added to compounds containing sulfhydryl groups. The absorbance was measured at $412 \mathrm{~nm}$ after $10 \mathrm{~min}$. Total reduced glutathione content was expressed as $\mathrm{nmol} / \mathrm{mg}$ of protein.

\section{Molecular Analysis}

DNA samples required for the DNA fragmentation analysis of normal and experimental mice were isolated from liver tissues by the method described previously by Kanno et al. [35]. The DNA fragmentation assay was performed by electrophoresis on genomic DNA samples using agarose/EtBr gel following the procedure described by Sellins and Cohen [36].

\section{Histopathological Examination}

Some liver tissue collected from each group was randomly selected for light microscopy. Samples were fixed in formalin solution and embedded in paraffin. The liver was then sectioned in the sagittal plane and stained with hematoxylin-eosin [37]. The nonalcoholic steatohepatitis (NAS) calculation system was applied to evaluate the steatosis, inflammation, and ballooning [38].

\section{Statistical Analysis}

All experiences and statistical analyses were made in triplicate. All results are expressed as the mean \pm standard deviation. Statistical analysis was performed with SPSS 17.0 statistical package for Windows (SPSS, Inc., Chicago, IL). A two-way ANOVA followed by Tukey's post-hoc test was performed to compare treatment and control groups. Statistical significance was set at $a=0.05$.

\section{Results}

In vitro antioxidant activity of E.s.spinosus flower

\section{Amounts Of Polyphenols And Flavonoids}

The obtained values for total phenolic (TPC) and flavonoid contents are summarized in Table 1. The methanolic extract was found to have a high amount of phenolic content $(895.14 \mathrm{mg}$ gallic acid $/ \mathrm{g}$ of extract) and the ethyl acetate extract has been found to be rich in flavonoids ( $215.36 \mathrm{mg}$ quercetin $/ \mathrm{g}$ of extract). 
Table 1

Amount of polyphenols, flavonoids, sterols andtriterpens in the methanolic extract of EchinopsspinosissimusTurra subsp. spinosus

\begin{tabular}{|lll|}
\hline Extracts & $\begin{array}{l}\text { Total phenolics } \\
\text { (mg gallic acid/g of extract) }\end{array}$ & $\begin{array}{l}\text { Total flavonoids } \\
\text { (mg quercetin/g of extract) }\end{array}$ \\
\hline Hexane & $113.71 \pm 0.11$ & $57.02 \pm 0.33$ \\
\hline Dichloromethane & $216.33 \pm 0.52$ & $92.34 \pm 1.01$ \\
\hline Ethylacetate & $485.27 \pm 0.26$ & $215.36 \pm 0.88$ \\
\hline Methanol & $895.14 \pm 0.12$ & $190.53 \pm 0.25$ \\
\hline Each value represents the mean \pm SD of three experiments \\
\hline
\end{tabular}

\section{Preliminary Qualitative Phytochemical Analysis}

Phytochemical screening of Tunisian Echinops spinosus flower heads extracts are given in Table 2 and indicated that the plant contains different chemical classes of active constituents, such as flavonoids, sterols, triterpenoids etc. Our results demonstrated that the ethyl acetate extract of this plant was found to have more constituents compared to other extracts and the flower heads of Echinops spinosus are showing the presence of flavonoids in methanolic extract but adequately present in ethyl acetate extract. The concentration of Triterpenoids is highly in ethyl acetate extract, but adequately present in hexane and dichloromethane extracts.

Table 2

Phytochemical analysis of Echinopsspinosus flower heads extracts.

\begin{tabular}{|lllll|}
\hline $\begin{array}{l}\text { Phytochemicals } \\
\text { analysis }\end{array}$ & \multicolumn{3}{l}{ Solvent extracts } & \\
\cline { 2 - 5 } & $\begin{array}{l}\text { Hexane } \\
\text { extract }\end{array}$ & $\begin{array}{l}\text { Dichloromethane } \\
\text { extract }\end{array}$ & $\begin{array}{l}\text { Ethyl acetate } \\
\text { extract }\end{array}$ & $\begin{array}{l}\text { Methanolic } \\
\text { extract }\end{array}$ \\
\hline Triterpenoids & + & + & ++ & - \\
\hline Quinones & - & - & + & + \\
\hline Alkaloids & - & - & - & ++ \\
\hline Flavonoids & - & - & + & - \\
\hline Tropolones & - & - & - & \\
\hline Each value represents the mean \pm SD of three experiments & & + \\
\hline
\end{tabular}


The effect of antioxidants on DPPH radical was thought to be due to their hydrogen donating ability. DPPH is a stable free radical and accepts an electron or hydrogen radical to become a stable diamagnetic molecule. Comparing the $\mathrm{EC}_{50}$ values with those of $\mathrm{BHT}$ and $\mathrm{a}$ - tocopherol which were 0.026 and $0.019 \mathrm{mg} / \mathrm{mL}$ respectively, we observed that $\mathrm{MeOH}$ extract of E.s.spinosus flower heads was potentially active and presented $\mathrm{EC}_{50}=0.100 \mathrm{mg} / \mathrm{mL}$, followed by ethyl acetate one $\left(\mathrm{EC}_{50}=\right.$ $0.150 \mathrm{mg} / \mathrm{mL}$ ). The results of DPPH radical-scavenging assay of different extracts are shown in Fig. 1 .

\section{FRAP assay}

The reducing power assay is often used to evaluate the ability of an antioxidant to donate an electron. In this assay, the ability of E.s.spinosus extracts to reduce $\mathrm{Fe}^{3+}$ to $\mathrm{Fe}^{2+}$ was determined. Reducing power increased with the concentration of the extracts. All analyzed samples demonstrated significant antioxidant capacities with FRAP test except the hexane and dichloromethane extracts of this plant. In fact, the methanolic extract showed the highest ability to reduce $\mathrm{Fe}^{3+}$ (Fig. 2).

$\beta$ - Carotene Bleaching Assay

The antioxidant activity through $\beta$-carotene-linoleate system of the four extracts of E.s. spinosus flower is measured by the ability of a compound to minimize the loss of $\beta$-carotene during the oxidation of linoleic acid in an emulsified aqueous system. The antioxidant activity coefficient (AAC) was compared with butylated hydroxyanisole and it is presented in Table 3.

Table 3

Antioxidant activity coefficient (ACC) of extracts from Echinops TURRA subsp. spinosusflower heads and BHA according to a $\beta$ carotene bleaching assay.

\begin{tabular}{|lc|}
\hline Extracts & AAC $^{\text {a }}$ \\
\hline Hexane & 164.30 \\
\hline Dichloromethane & 187.42 \\
\hline Ethylacetate & 223.71 \\
\hline Methanol & 243.95 \\
\hline aValues are expressed as antioxidant activity coefficient (ACC). \\
\hline
\end{tabular}

The methanol extract are endowed with the highest activity. This activity may be attributed to the content of phenolic components in this extract of E.s.spinosus flower.

In vivo antioxidant activity of E.s.spinosus flower 
Effect of E.s.spinosus flower on body weight

Results presented in Fig. 3 indicated that body weights of hypercholesterolemic mice were significantly increased, while body weight of the group co-treated with E.s.spinosus flower methanolic extract was similar to that of control group.

Effect of E.s.spinosus flower on lipid peroxidation, and protein oxidation in the liver

Our findings revealed changes in the levels of lipid peroxidation products in the experimental groups. In the hypercholesterolemic mice, MDA level, index of lipid peroxidation showed a significant increase $(P=$ 0.003). Similarly, a remarkable rise in AOPP and PCO levels in the liver was also evident in the hypercholesterolemic group, when compared with controls $(P<0.001$; $P=0.076)($ Table 4$)$.

Supplementation of E.s.spinosus flower methanolic extract to the hypercholesterolemic group ameliorated all parameters cited above.

Table 4

Levels of MDA, PCO and AOPP in the liver of controls and hypercholesterolemic mice associated with Echinopsspinosusmethanolic extract during 30 days.

\begin{tabular}{|c|c|c|c|c|}
\hline $\begin{array}{l}\text { Parameters } \\
\text { and treatment }\end{array}$ & Controls & Cholesterol & $\begin{array}{l}\text { Cholesterol } \\
\text { +E100 }\end{array}$ & $\begin{array}{l}\text { Cholesterol } \\
+ \text { E200 }\end{array}$ \\
\hline $\begin{array}{l}\text { MDA(nmol of MDA/mg } \\
\text { protein) }\end{array}$ & $\begin{array}{l}143.82 \pm \\
14.83^{c}\end{array}$ & $\begin{array}{l}203.40 \pm \\
16.30^{a}\end{array}$ & $\begin{array}{l}176.27 \pm \\
11.15^{\mathrm{b}}\end{array}$ & $\begin{array}{l}140.5 \pm \\
17.27^{c}\end{array}$ \\
\hline PCO(nmol/mg protein) & $0.53 \pm 0.14^{c}$ & $1.03 \pm 0.19^{a}$ & $0.98 \pm 0.33^{c}$ & $0.67 \pm 0.21^{c}$ \\
\hline AOPP ( $\mu \mathrm{mol} / \mathrm{mg}$ protein) & $0.02 \pm 0.002^{c}$ & $0.07 \pm 0.004^{a}$ & $0.06 \pm 0.001^{a}$ & $0.04 \pm 0.003^{b}$ \\
\hline \multicolumn{5}{|c|}{ Values are expressed as means \pm S.D for 10 animals in each group. } \\
\hline \multicolumn{5}{|c|}{ Values bearing the same letter showed no significant difference $(P<0.05)$. } \\
\hline
\end{tabular}

Effect of E.s.spinosus flower on enzymatic and non-enzymatic antioxidants in the liver

Our results showed the effect of Echinops spinosus methanolic extract on enzymatic and nonenzymatic antioxidants of control and experimental animals. ANOVA demonstrated a significant rise $(p<0.001)$ in the activities of enzymatic antioxidants (SOD and GPx) (Table 5) was observed as well as a remarkable decrease $(p<0.001)$ in the level of GSH in the hypercholesterolemic mice compared with controls. Administration of E.s.spinosus flower methanolic extract highly improved the antioxidant status in the liver tissue compared with hypercholesterolemic group. 
Table 5

Liver enzymatic and non-enzymatic activities of adult mice, controls and treated with cholesterol, cholesterol associated to 100 and $200 \mathrm{mg} / \mathrm{kg}$ of methanolic extract (E100, E200) of Echinopsspinosusrespectively during 30 days.

\begin{tabular}{|lllll|}
\hline $\begin{array}{l}\text { Parameters } \\
\text { and treatment }\end{array}$ & Controls & Cholesterol & $\begin{array}{l}\text { Cholesterol } \\
+\mathrm{E} 100\end{array}$ & $\begin{array}{l}\text { Cholesterol } \\
+ \text { E200 }\end{array}$ \\
\hline $\begin{array}{l}\text { GPx (nmoles of GSH/min/mg } \\
\text { protein) }\end{array}$ & $\begin{array}{l}94.16 \pm \\
16.69^{\mathrm{a}}\end{array}$ & $\begin{array}{l}55.60 \pm \\
12.57^{\mathrm{C}}\end{array}$ & $\begin{array}{l}78.21 \pm \\
13.46^{\mathrm{b}}\end{array}$ & $\begin{array}{l}95.12 \pm \\
1.51^{\mathrm{a}}\end{array}$ \\
\hline SOD (units/mg protein) & $23.34 \pm 4.22^{\mathrm{a}}$ & $12.76 \pm 4.17^{\mathrm{c}}$ & $18.43 \pm 2.11^{\mathrm{b}}$ & $\begin{array}{l}25.62 \pm \\
2.62^{\mathrm{a}}\end{array}$ \\
\hline GSH (nmol/mg protein) & $20.35 \pm 4.56^{\mathrm{a}}$ & $11.38 \pm 3.13^{\mathrm{c}}$ & $14.35 \pm 3.54^{\mathrm{b}}$ & $18.08 \pm 2.56^{\mathrm{a}}$ \\
\hline Values are expressed as means \pm S.D for 10 animals in each group. & & \\
\hline Values bearing the same letter showed no significant difference $(\mathrm{P}<0.05)$. & \\
\hline
\end{tabular}

Effect of E.s.spinosus flower on some plasma biomarkers of liver toxicity

Bilirubin level as well as AST and ALT activities were significantly increased $(P<0.001)$, respectively, in the hypercholesterolemic group, when compared with the controls (Table 6). Co-administration of Echinops spinosus methanolic extract to the hypercholesterolemic group significantly decreased plasma bilirubin, AST, and ALT to near normal values, as compared with the hypercholesterolemic mice.

Table 6

Plasma liver markers of adult mice, controls and treated with cholesterol, cholesterol associated to 100 and $200 \mathrm{mg} / \mathrm{kg}$ of methanolic extract (E100, E200) of Echinopsspinosus respectively during 30 days.

\begin{tabular}{|lllll|}
\hline $\begin{array}{l}\text { Parameters } \\
\text { and treatment }\end{array}$ & Controls & Cholesterol & $\begin{array}{l}\text { Cholesterol } \\
+\mathrm{E} 100\end{array}$ & $\begin{array}{l}\text { Cholesterol } \\
+\mathrm{E} 200\end{array}$ \\
\hline AST (UI/I) & $169.5 \pm 21.92^{\mathrm{C}}$ & $420 \pm 36.76^{\mathrm{a}}$ & $232.5 \pm 21.9^{\mathrm{b}}$ & $221 \pm 2.82^{\mathrm{b}}$ \\
\hline ALT $(\mathrm{UI} / \mathrm{I})$ & $37 \pm 8.48^{\mathrm{C}}$ & $59 \pm 4.24^{\mathrm{a}}$ & $43 \pm 2.82^{\mathrm{b}}$ & $34 \pm 2.81^{\mathrm{C}}$ \\
\hline ASAT/ALAT & $4.58^{\mathrm{C}}$ & $7.11^{\mathrm{a}}$ & $5.4^{\mathrm{b}}$ & $6.5^{\mathrm{b}}$ \\
\hline Bilirubin $(\mathrm{mg} / \mathrm{I})$ & $1.7 \pm 0.09^{\mathrm{b}}$ & $2.6 \pm 2.54^{\mathrm{a}}$ & $1.25 \pm 0.07^{\mathrm{b}}$ & $2.7 \pm 0.14^{\mathrm{a}}$ \\
\hline Values are expressed as means \pm S.D for 10 animals in each group. \\
\hline Values bearing the same letter showed no significant difference $(\mathrm{P}<0.05)$. \\
\hline
\end{tabular}


Table 7

Plasma lipid profile of adult mice, controls and treated with cholesterol, cholesterol associated to 100 and $200 \mathrm{mg} / \mathrm{kg}$ of methanolic extract (E100, E200) of Echinopsspinosusrespectively during 30 days.

\begin{tabular}{|c|c|c|c|c|}
\hline Parameters and treatments & Controls & Cholesterol & Cholesterol + E100 & Cholesterol + E200 \\
\hline Cholesterol (g/l) & $\begin{array}{l}2.49 \pm \\
0.04^{b}\end{array}$ & $\begin{array}{l}3.26 \pm \\
0.18^{a}\end{array}$ & $2.25 \pm 0.007^{b}$ & $1.88 \pm 0.028^{\mathrm{b}}$ \\
\hline Triglycerides (g/L) & $\begin{array}{l}1.08 \pm \\
0.16^{\mathrm{b}}\end{array}$ & $\begin{array}{l}1.83 \pm \\
0.06^{a}\end{array}$ & $0.81 \pm 0.07^{c}$ & $0.52 \pm 0.07^{c}$ \\
\hline $\mathrm{HDL}-\mathrm{C}(\mathrm{g} / \mathrm{L})$ & $\begin{array}{l}1.74 \pm \\
0.07^{a}\end{array}$ & $1.2 \pm 0.07^{b}$ & $1.37 \pm 0.06^{\mathrm{b}}$ & $1.63 \pm 0.06^{\mathrm{b}}$ \\
\hline LDL-C(g/L) & $0.20 \pm 0.05^{c}$ & $\begin{array}{l}1.42 \pm \\
0.07^{a}\end{array}$ & $0.18 \pm 0.02^{c}$ & $0.65 \pm 0.05^{b}$ \\
\hline Al & $0.43^{\mathrm{c}}$ & $1.71^{\mathrm{a}}$ & $0.64^{\mathrm{b}}$ & $0.15^{\mathrm{C}}$ \\
\hline \multicolumn{5}{|c|}{$\begin{array}{l}\text { LDL-C, low density lipoprotein cholesterol; HDL-C, high-density lipoprotein cholesterol; Al, Atherogenic } \\
\text { index. }\end{array}$} \\
\hline \multicolumn{5}{|c|}{ Values are expressed as means \pm S.D for 10 animals in each group. } \\
\hline
\end{tabular}

Effects of E.s.spinosus flower on lipid profile

The statistical analysis shows a significant increase in TC in mice from hypercholesterolemic group, when compared with those of controls $(p=0.001)$. It was also noted that triglyceride, LDL-C levels and atherogenic index significantly increased in the hypercholesterolemic group $(p<0.001)$, while HDL-C decreased, when compared to controls $(p<0.001)$. As compared to hypercholesterolemic mice, E.s.spinosus flower treatment significantly restored plasma cholesterol, triglyceride, LDL-C, and HDL-C to near normal values.

Effect of E.s.spinosus flower on DNA damage

As shown in Fig. 4, agarose gel of the DNA electrophoresis showed a DNA smearing, following hypercholesterolemic (lane 3) compared with the control group (lane 2). However, DNA isolated from the liver cells of E.s.spinosus flower treated-mice (lane 4) exhibited less smearing of DNA, compared with the hypercholesterolemic group. Co-administration of E.s.spinosus flower to the hypercholesterolemic group significantly reduced the DNA damage (lane 4).

Liver histopathological analysis

Histopathological examination of control group (Fig. 4A) showed unremarkable changes with normal architecture and appearance of the central vein with a radiating pattern of cell plates that were normal in 
shape and size. The hypercholesterolemic regime induced degenerative changes, such as the hepatic steatosis, leucocytes infiltration, and hepatocyte vacuolization (Fig. 4B). The administration of E.s.spinosus flower to the hypercholesterolemic provoked a marked improvement in the hepatocyte structure (Fig. 4 (C,D).

\section{Discussion}

Lipid disorders, which encompass hypercholesterolemia, hypertriglyceridemia, or their combination, are prevalent in modern societies [39]. Hyperlipidemia is commonly associated with atherosclerotic vascular diseases and is present as a risk factor for many diseases [10, 40]. During the last few decades, numerous epidemiological, laboratory, and clinical studies have demonstrated a connection between high cholesterol and increased risk for atherosclerosis. Potential hypocholesterolemic pharmaceuticals and food products are continuously being developed to control hypercholesterolemia in humans. The extrapolation of hypocholesterolemic mechanisms what is relevant in vivo is not directly possible. In this context, the aims of the present work were to evaluate the effects of E.s.spinosus flower when supplemented in hypercholesterolemic diet at a nutritional dose.

In our study, E.s.spinosus flower was reported to reduce body weight gain compared with the hypercholesterolemic group. Moreover, with the longer time needed for E.s.spinosus flower treatment, the retardation of body weight gain in rats was obvious. This might indicate that the plant could be used as weight loss agent for obese humans, which might be because of the binding of lipid in the gastrointestinal tract thereby reducing fat absorption [41].

Treatment of hypercholesterolemic mice with E.s.spinosus flower methanolic extract induced marked significant decrease of plasma total cholesterol, triglycerides and LDL-cholesterol concentrations as compared to the hypercholesterolemic mice. Additionally, E.s.spinosus flower extract improved the level of HDL-cholesterol, which may be due to the ability of the plant to hasten the decomposition of free radical species generated during cholesterol administration $[42,43]$. Where, HDL-C is a free radical scavenger and prevents peroxidation of beta lipoproteins [44]. The reduction in HDL following cholesterol feeding may be due, also, to contributed acceleration of apoA-I clearance from the plasma based on cholesterol-enriched diets [45]. The high level of LDL-cholesterol found in hypercholesterolemic rats may be attributed to a down regulation in LDL receptors by cholesterol and saturated fatty acids included in the diet [46]. The hypercholesterolemic mice exhibited a profound increase in atherogenic index as compared to normal ones. This atherogenicity thought to be due to the atherogenic lipoprotein subclasses commonly associated with hyperlipidemia [47]. Our result indicated that, treatment using E.s.spinosus flower exhibited significant decrease of $\mathrm{Al}$, as compared to hypercholesterolemic mice that might be ascribed to their plasma lipid-lowering activity. The E.s. spinosus showed high antihyperlipidemic activity in mice. This could be explained by the richness of the plant in polysaccharides and $\beta$-carotene. In fact, Godard [43] has reported that polysaccharides are strongly liable with the observed hypolipidemic effects. Shaish et al. [48] demonstrate that $\beta$-carotene is responsible for an increase in HDL-cholesterol. 
Other biomarkers of liver toxicity like AST and ALT [49] were also studied in the present work. Plasma AST and ALT activities were significantly high in high-cholesterol fed diet than in normal mice; these results agreed with those of Sudhahar et al. [50]. The increase of these activities suggested their leakage from the liver to the plasma [51]. The biochemical alterations were correlated with a marked increase in liver lipid and protein oxidation. The lipid peroxidation, measured as thiobarbituric acid reactive species, is a free-radical mediated propagation of oxidative insult to polyunsaturated fatty acids involving several types of free radicals [52]. The hypercholesterolemic mice of the present study exhibited high significant elevation of hepatic MDA, AOPP and PCO concentrations as compared to normal control group. An increase of lipid peroxidation, in animals fed with a high cholesterol diet has been previously reported [53, 54]. There was a positive correlation between plasma total cholesterol and triacylglycerol concentrations and free radicals generation [55]. An abnormal rise in lipid and protein oxidation was reduced with plant administration, due to their antioxidant activities and this antioxidant compounds, emphasized through in vitro experiments. However, the obtained results could be attributed to the reported antioxidant effects of E.s.spinosus flower which in turn lead to decreased free radical generation and decreased oxidative damage of the liver, the main organ involved in cholesterol biosynthesis. Indeed in the current study, oxidative stress was obvious in cholesterol rich diet fed-mice as evidenced by the increase in plasma lipid peroxide level coupled with decreased SOD, GPx and catalase activities. Similar results were previously reported [56]. Supplementation with E.s.spinosus flower was found to increase the activity of the antioxidant enzymes respectively, as compared with the hypercholesterolemic mice. A reduction of these enzymes activities is associated with the accumulation of highly reactive free radicals, leading to deleterious effects such as loss of integrity and function of cell membranes. When they are present in high concentrations, free radicals are able to interact with the enzymes and inactivate them.

Apart from enzymatic antioxidants, non-enzymatic antioxidants and hepatic reduced glutathione play a vital role in protecting cells from oxidative damage. GSH in hypercholesterolemic mice decreased significantly when compared with the normal ones. These reductions may be due to the increased utilization of these anti-oxidants for quenching enormous free radicals produced during hypercholesterolemic condition. Thus, the increased GSH content in hypercholesterolemic group may be attributed to the ability of E.s.spinosus flower to improve the defensive nature of liver against free radicals. Free radicals also attack DNA bases, therefore causing mutagenic lesions. In fact, hypercholesterolemic diet resulted in a significant DNA fragmentation with a subsequent formation of a DNA smear on agarose gel.

The damage induced by hypercholesterolemic diet in the liver of adult mice was confirmed by histological changes, including a marked leucocyte infiltration, steatosis, and apoptosis. In fact, hypercholesterolemic diet caused several liver histological injuries such as distortion in tissue histoarchitecture, congestion of the central vein, sinusoidal dilatation, generalized congestion, hemorrhage, and degenerative changes. Co-treatment of mice with E.s.spinosus flower could prevent DNA and histological damages in hypercholesterolemic mice due to its powerful antioxidant capacity. 
In conclusion, the results obtained herein indicate that Echinops spinosissimus Turra subsp. spinosus a protective effect on high-cholesterol diet induced liver damage in mice, possibly through its antioxidant properties. We therefore propose that Echinops spinosissimus may be beneficial in reducing hypercholesterolemia in patients, but further studies are required to determine the optimal doses of this compound.

\section{Declarations}

Conflicts of interest

The authors declare that there are no conflicts of interest.

Funding

This work was supported by the Ministry of Higher Education and Scientific Research in Tunisia. Acknowledgments

The present work was supported by grants from the DGRST (Direction Générale de la Recherche Scientifque et Technique-Tunisie.

\section{References}

1.

Deepa PR, Varalakshmi P. Atheroprotective effect of exogenous heparin-derivative treatment on the aortic disturbances and lipoprotein oxidation in hypercholester- olemic diet fed rats. Clin Chim Acta. 2005;355:119-30.

2.

Sathivel A, Raghavendran HR, Srinivasan P, Devaki T. Anti-peroxidative and anti-hyperlipidemic nature of Ulva lactuca crude polysaccharide on D-galactosamine induced hepatitis in rats. Food Chem Toxicol. 2008;46:3262-7.

3.

Ballantyne CM. Low-density lipoproteins and risk for coronary artery disease. Am J Cardiol. 1998;82:312.

4. Luoa Q-F, Suna L, Sib J-Y, Chenb D-H. Hypocholesterolemic effect of stilbenes containing extract-fraction from Cajanus cajan L. on diet-induced hypercholesterolemia in mice. Phytomedicine. 2008;15:932-9. 5 .

Sparks DL, Scheff SW, Hunsaker JC, Liu H, Landers T, Gross DR. Induction of Alzheimer-like beta-amyloid immunoreactivity in the brains of rabbits with dietary cholesterol. Exp Neurol. 1994;126:88-94. 6.

Prasanthi J, Schommer E, Thomasson S, Thompson A, Feist G, Ghribi O. Regulation of $\beta$-amyloid levels in the brain of cholesterol-fed rabbit, a model system for sporadic Alzheimer's disease. Mechan Ag Dev. 2008;129:649-55.

7. 
Sharma S, Prasanthi J, Schommer E, Feist G, Ghribi O. Hypercholesterolemiainduced A $\beta$ accumulation in rabbit brain is associated with alteration in IGF-1 signaling. Neurobiological Diseases. 2008;32:426-32. 8.

Granholm AC, Bimonte-Nelson HA, Moore AB, Nelson ME, Freeman LR, Sambamurti K. Effects of a saturated fat and high cholesterol diet on memory and hippocampal morphology in themiddle-aged rat. $J$ Alz Dis. 2008;14:133-45.

9.

Slim RM, Toborek M, Watkins BA, Boissonneault GA, Hennig B. Susceptibility to hepatic oxidative stress in rabbits fed different animal and plant fats. J Am Coll Nut. 1996;15:289-94.

10.

Aronow WS. Managing hyperlipidaemia in the elderly: special considerations for a population at high risk. Drug Ag. 2006;23:181-9.

11.

Dickel ML, Rates SM, Ritter MR. Plants popularly used for losing weight purposes in Porto Alegre, South Brazil. Journal Ethnopharmacol. 2007;109:60-71.

12.

Kadri A, Chobba I, Zarai Z, Békir A, Gharsallah N, Damak M, Gdoura R. Chemical constituents and antioxidant activity of the essential oil from aerial parts of Artemisia herba-alba grown in Tunisian semiarid region. Af J Biotech. 2011;10:2923-29.

13.

Halliwell B, Gutteridge JMC. Role of free radicals and catalytic metal ions in human disease: An overview. Method Enzymol. 1990;186:80-5.

14.

Guo D, Cui Y, Lou Z, Gao C, Huang L. Chin Trad Her Med. 1992;23:3.

15.

Floc'h EL, Boulos E. Vela. Ministère de L'environnement et du Développement Durable, Banque Nationale de Gènes. 2010.

16.

Hymete A, Iversen TH, Rohloff J, Erko B. Phytomedecine. 2005;12:675.

17.

Bouattour E, Fakhfakh J, Frikha Dammak D, Jabou K, Damak M, Mezghani Jarraya R. Hexane extract of Echinops spinosissimus Turra subsp. spinosus from Tunisia: A potential source of acetylated sterols. Investigation of its biological activities. 2017.

18.

Singleton VL, Rossi JA. Colorimetry of total phenolics with phosphomolybdic-phosphotungstic acid reagents. Am J Enol Vitic. 1965;16:144-58.

19.

Arvouet-Grand A, Vennat B, Pourrat A, Legret P. Standardisation d'un extrait de propolis et identification des principaux constituants. J Pharm Belg. 1994;49:462-8.

20. 
Harborne JB. Biochemistry of phenolic compounds. London: Academic press; 1964. pp. 93-111. 21.

Oyaizu M. Studies on products of browning reaction: Antioxidative activities of products of browning reaction prepared from glucosamine. Japanese Journal of Nutrition. 1986;44:307-15.

22.

Brand W, Cuvelier ME, Berset C. Use of a Free Radical Method to Evaluate Antioxidant Activity. Food of sciences Technology. 1995;28:25-30.

23.

Chevolleau S, Debal A, Ucciani E. Détermination de l'activité anti-oxydante d'extraits végétaux. Revue française des Corps Gras. 1992;39:3.

24.

Council of European Communities. Council instructions about the protection of living animals used in scientific investigations. Official Journal of the European Communities, (JO 86/609/CEE), L358, pp. 1986.1-18.

25.

Gargouri M, Soussi A, Akrouti A, Magné C, El Feki A. Ameliorative effects of Spurilina platensis against lead-induced nephrotoxicity in newborn rats: modulation of oxidative stress and histopathological changes. EXCLI Journal. 2018;17:215-32.

26.

Lowry OH, Rosenbrough NJ, Farr AL. Protein measurement with the Folin phenol reagent. The Journal of Biological Chemistry. 1951;193:265-75.

27.

Draper $\mathrm{HH}$, Hadley M. Malondialdehyde determination as index of lipid peroxidation. Methods of Enzymology. 1990;186:421-31.

28.

Witko V, Nguyen AT, Descamps-Latscha B. Microtiter plate assay for phagocytederived taurine chloramines. J Clin Lab Anal. 1992;6:47-53.

29.

Reznick AZ, Packer L. Oxidative damage to proteins: spectrophotometric method for carbonyl. Methods of Enzymology. 1994;233:357-63.

30.

Beauchamp C, Fridovich I. Superoxydedimutase: improved assays and an assay applicable to acrylamide gel. Analatical Biochemistry. 1971;44:276-87.

31.

Flohe L, Gunzler WA. Assays of glutathione peroxidase. Methods of Enzymology. 1984;105:114-21. 32.

Ellman GL. Tissue sulfhydryl groups. Archives of Biochemistry Biophysis. 1959;82:70-7. 33.

Jollow DJ, Mitchell JR, Zampaglione N. Bromobenzene-induced liver necrosis. Protective role of glutathioneand evidence for 3, 4-bromobenzene oxide as the hepatotoxic metabolite. Pharmacology. 
1974;11:151-69.

34.

Friedewald WT. Estimation of concentration of low-density lipoprotein cholesterol in plasma without use of the preparative ultracentrifuge. Clin Chem. 1972;18:499-502.

35.

Kanno S, Ishikawsa M, Takayanagi M, Takayanagi Y, Sasaki K. Potentiation of acetaminophen hepatotoxicity by doxapram in mouse primary cultured hepatocytes. Biological Pharmaceutical Bulletin. 2000;23:446-50.

36.

Sellins KS, Cohen JJ. Nuclear changes in the cytotoxic T lymphocyte-induced model of apoptosis. Immunological Review. 1995;146:241-66.

37.

Gabe M.. Masson. Techniques histologiques. Paris: 838 - 79; 1968.

38.

Kleiner DE, Brunt EM, Van Natta M, Behling C, Contos MJ, Cummings OW, Ferrell LD, Liu YC, Torbenson MS, Unalp-Arida A, Yeh M, McCullough AJ, Sanyal AJ. Design and validation of a histological scoring system for nonalcoholic fatty liver disease. Hepatology. 2005;41:1313-21.

39.

Park YW, Zhu S, Palaniappan L, Heshka S, Carnethon MR, Heymsfield SB. The metabolic syndrome: prevalence and associated risk factor findings in the US population from the Third National Health and Nutrition Examination Survey. Arch Intern Med. 2003;163:1988-94.

40 .

Csaszar A. Hypertriglyceridemia, the coronary heart disease risk marker "solved". Acta Physiol Hung. 2005;92:109-20.

41.

Shields KM, Smock N, McQueen CE, Bryant PJ. Chitosan for weight loss and cholesterol management. American Journal Health System Pharmacology. 2003;60:1310-12.

42.

Raghavendran HR, Sathivel A, Devaki T. Effect of Sargassum polycystum (Phaeophyceae)-sulfated polysaccharide extract against acetaminophen-induced hyperlipidemia during toxic hepatitis in experimental rats. Molocular Cellular Biochemistry. 2005;276:89-96.

43.

Godard M, De'corde K, Ventura E, Soteras G, Baccou JC, Cristol JP, Rouanet JM. Polysaccharides from the green alga Ulva rigida improve the antioxidant status and prevent fatty streak lesions in the high cholesterol fed hamster, an animal model of nutritionally-induced atherosclerosis. Food Chem. 2009;115:176-80.

44.

Chander R, Kapoor NK. High-density lipoprotein is a scavenger of superoxide anions. Biochemical Pharmacollogy. 1990;40:1663-5.

45 . 
Sorci-Thomas M, Prack MM, Dashti N, Johnson F, Rudel LL, Williams DL. Differential effects of dietary fat on the tissue-specific expression of the apolipoprotein A-I gene: relationship to plasma concentration of high density lipoproteins. J Lipid Res. 1989;30:1397-403.

46.

Mustad VA, Etherton TD, Cooper AD, Mastro AM, Pearson TA, Jonnalagadda SS, Kris-Etherton PM. Reducing saturated fat intake is associated with increased levels of LDL receptors on mononuclear cells in healthy men and women. J Lipid Res. 1997;38:459-68.

47.

Hodis NH. Triglyceride-rich lipoprotein remnant particles and risk of atherosclerosis. Circulation. 1999;99:2852-4.

48.

Shaish A, Harari A, Hananshvili L, Cohen H, Bitzur R, Luvish T, Ulman E, Golan M, Ben-Amotz A, Gavish D, Rotstein Z, Harats D. 9-cis beta-carotene-rich powder of the alga Dunaliella bardawil increases plasma HDL-cholesterol in fibrate-treated patients. Atherosclerosis. 2006;189:215-21.

49.

Rahman MF, Siddiqui MK, Jamil K. Effects of Vepacide (Azadirachta indica) on aspartate and alanine aminotransferase profiles in sub-chronic study with rats. Journal of Human Experimental Toxicology. $2001 ; 20: 243-9$.

50.

Sudhahar V, Kumar SA, Sudharsan PT, Varalakshmi P. Protective effect of lupeol and its ester on cardiac abnormalities in experimental hypercholesterolemia. Vasculair Pharmacology. 2007;46:412-8. 51.

Hanley KS, Schmidt E, Schmidt FM. Enzymes in serum, their volumes in diagnosis. Springfield: Charles Thomas; 1986. pp. 79-81.

52.

Korkina LG, Afanas'ev IB. Antioxidant and chelating properties of flavonoids. Advances of Pharmacology. 1997;38:151-63.

53.

Shukla R, Gupta S, Gambhir JK, Prabhu KM, Murthy PS. Antioxidant effect of aqueous extract of the bark of Ficus bengalensis in hypercholesterolemic rabbits. J Ethnopharmacol. 2004;92:47-51.

54.

Visavadiya NP, Narasimhacharya AV. Hypocholesteremic and antioxidant effects of Withania somnifera (Dunal) in hypercholesteremic rats. Phytomedicine. 2007;14:136-42.

55.

Chen J, Li X. Hypolipidemic effect of flavonoids from mulberry leaves in triton WR-1339 induced hyperlipidemic mice. Asia Pacific Journal of Clinical Nutrition. 2007;16:290-4.

56.

Garjani A, Fathiazad F, Zakheri A, Akbari NA, Azarmie Y, Fakhrjoo A. The effect of total extract of Securigera securidaca L. seeds on serum lipid profiles, antioxidant status, and vascular function in hypercholesterolemic rats. J Ethnopharmacol. 2009;126:525-32. 
Figures

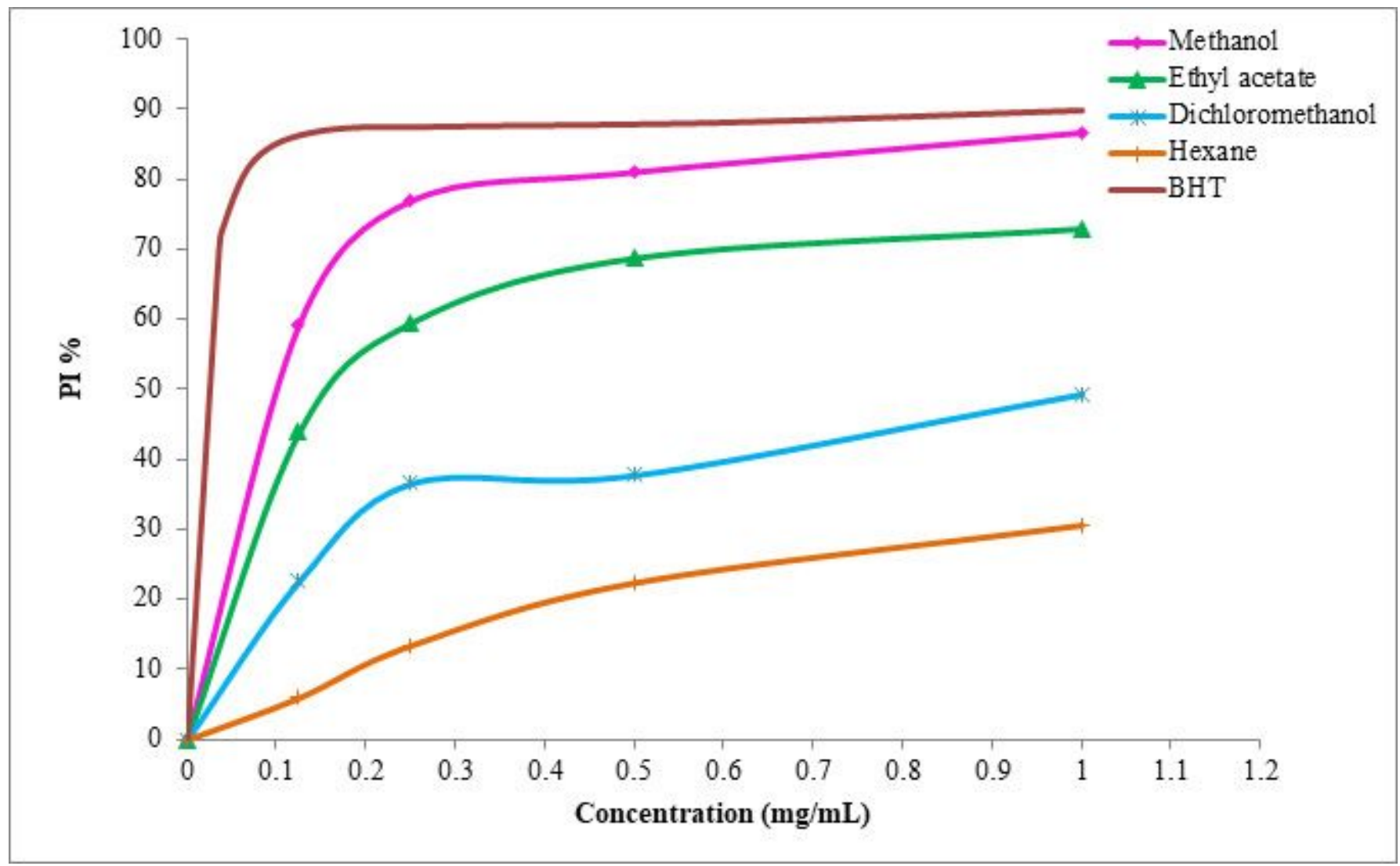

Figure 1

DPPH free radical scavenging activity of Echinops spinosus $L$ extracts in comparison with BHT used as standard. 


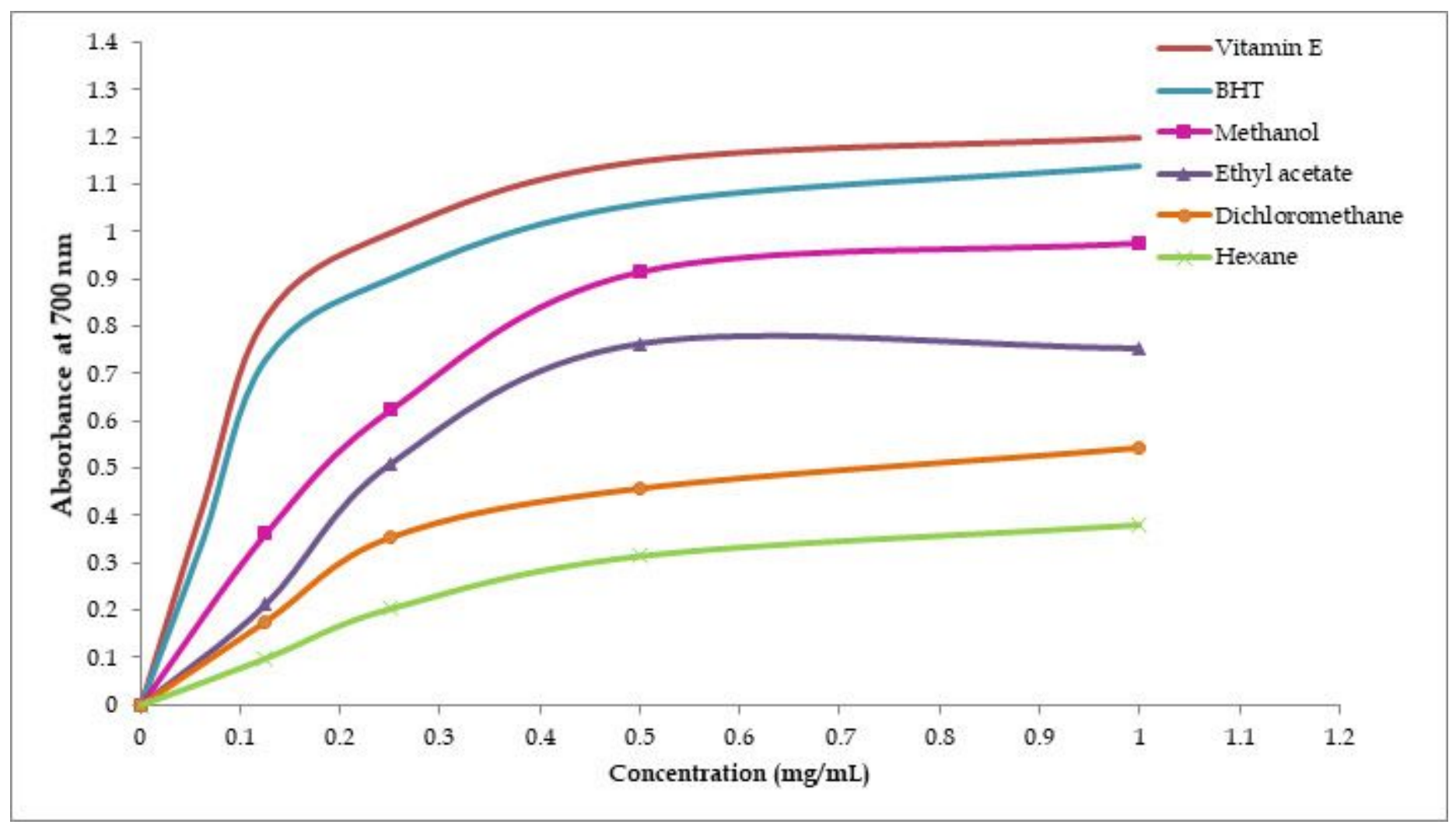

Figure 2

Reducing power activities of Echinops spinosus $L$ extracts in comparison with $\mathrm{BHT}$ and vitamin $\mathrm{E}$ used as standard

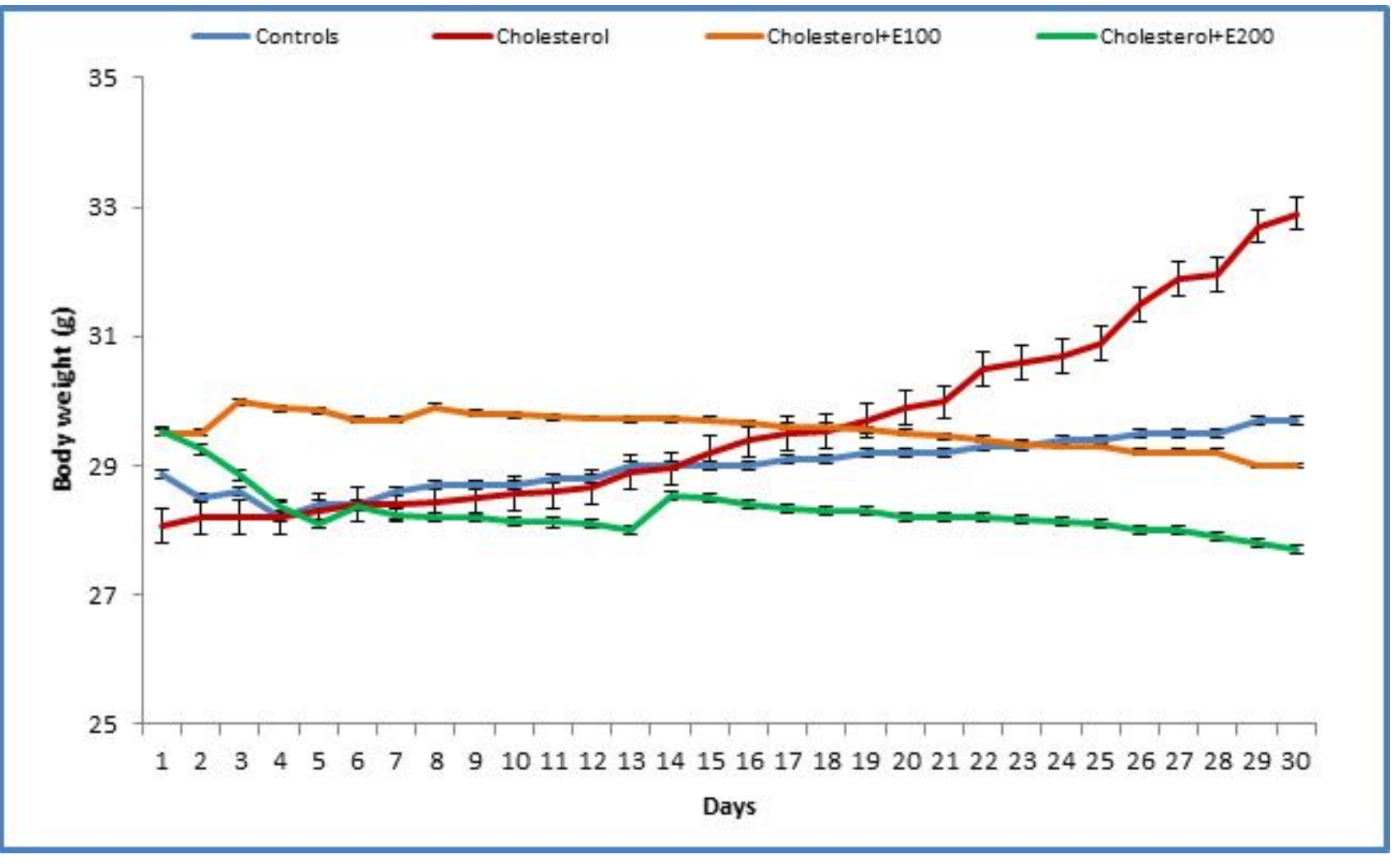

Figure 3 
Mean body weights of controls, hypercholesteromic and hypercholesteromic mice associated with Echinops spinosus methanolic extract during 30 days.

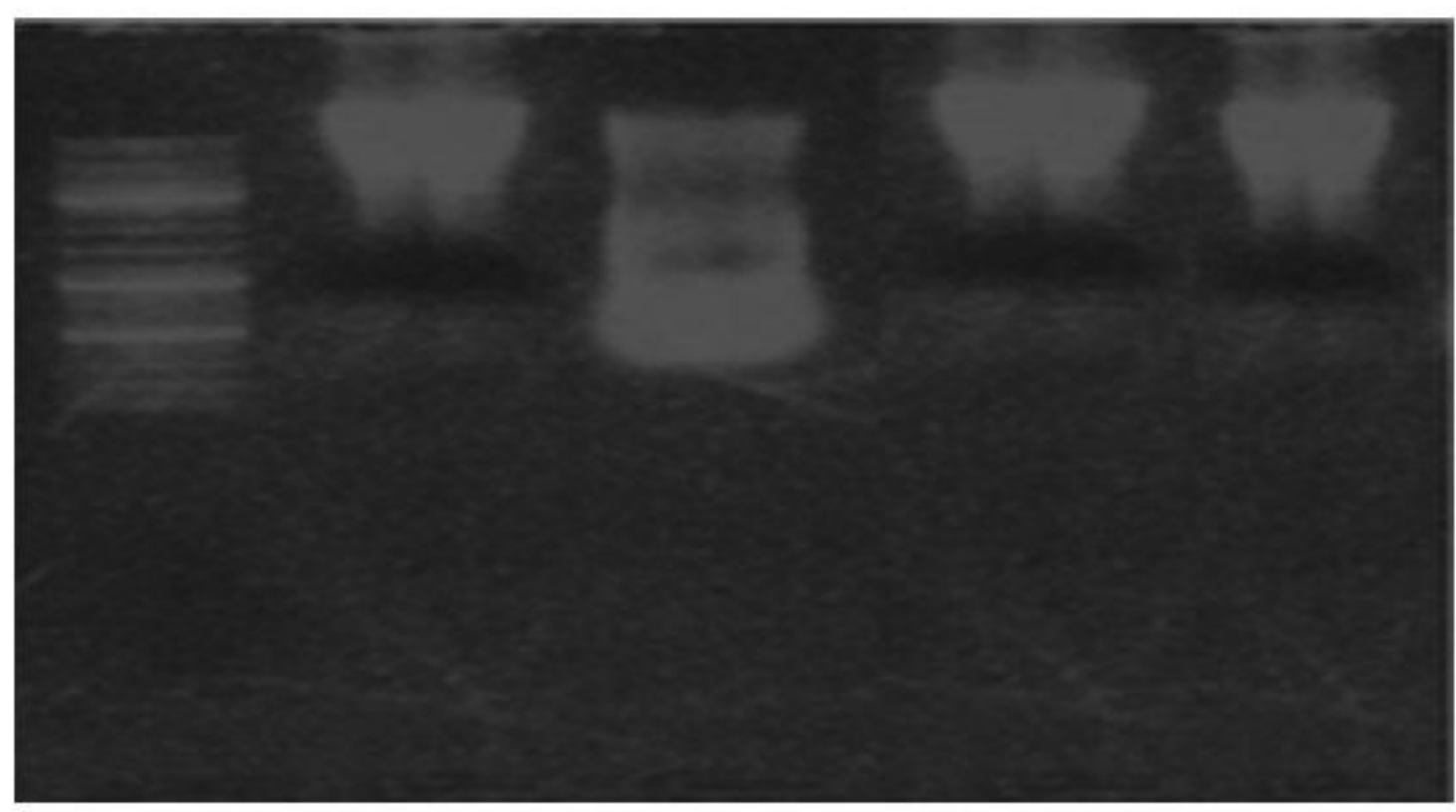

Figure 4

Agarose gel electrophoresis of DNA fragmentation. M marker, lane 1 control group, lane 2 Cholesterol, lane 3 Cholesterol+E100, lane 4 Cholesterol+E200. 

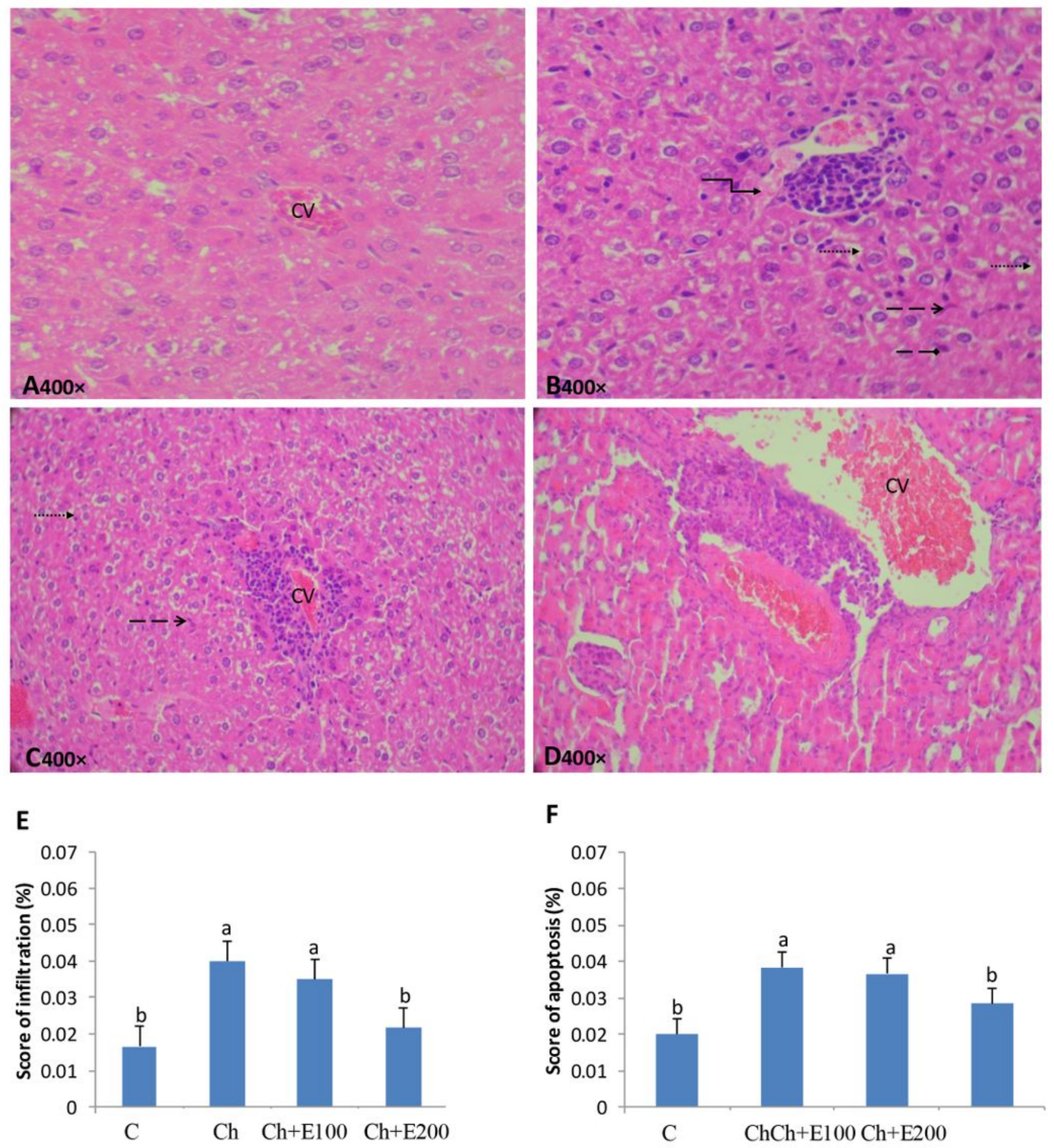

\section{Figure 5}

Liver histological sections (H\&E) of controls (A), hypercholesteromic group (B) and hypercholesteromic group associated with the methanolic extract of Echinops spinosis methanolic extract (C, D). E-F: Histological NAS scores of liver tissues The arrows indicate: Leucocyte infiltration: Necrosis ; Apoptosis ; : Hepatocyte vacuolization 